\title{
The Effect of Financial Leverage on the Islamic Banks' Performance in the Gulf Cooperation Council (GCC) Countries
}

\author{
Abdesslam Menacer ${ }^{1}$, Abdulazeez Y. H. Saif-Alyousfi ${ }^{2,3}$ \& Nor Hayati Ahmad ${ }^{1}$ \\ ${ }^{1}$ Islamic Business School, Universiti Utara Malaysia, Kedah, Malaysia \\ ${ }^{2}$ Department of Finance, College of Business Administration, University of Hafr Albatin, Hafr Albatin, Saudi Arabia \\ ${ }^{3}$ Department of Finance and Banking, Faculty of Administrative Sciences, Taiz University, Taiz, Yemen \\ Correspondence: Abdulazeez Y. H. Saif-Alyousfi, Department of Finance, College of Business Administration, \\ University of Hafr Albatin, Saudi Arabia.
}

Received: August 15, 2019

Accepted: October 6, 2019

Online Published: October 15, 2019

doi:10.5430/ijfr.v11n1p13

URL: https://doi.org/10.5430/ijfr.v11n1p13

\begin{abstract}
This study examines the impact of the financial leverage on the Islamic banks' performance in the GCC countries during the period from 2005-2017. The population of this study included the Islamic banks in the GCC countries. Thirteen years data of 25 listed Islamic banks in the GCC countries were used, wereby these data were retrieved from the Thomson Reuters DataStream. This study utilized the fixed effect regression model. The findings show that the financial leverage a has significant impact on the performance of the Islamic banks' performance in the GCC region. More specifically, the financial leverage has a positive and significant impact on ROA, ROE, and Tobin's Q of the Islamic banks in the GCC countries, thus indicating that the higher is the financial leverage the higher is the performance of the Islamic banks in the GCC region. However, the results of this study do not provide evidence to support the Agency Cost Theory that implies a decrease in the performance when equity ratio is increased. On the other hand, the findings provide evidence to support the Signaling Theory that argues that banks are expected to have a better performance credibly in transmitting this information through the higher capital. The findings imply that the level of financial leverage committed by the Islamic banks depends on their flexibility in adjusting their debt value and earning power.
\end{abstract}

Keywords: financial leverage, bank's performance, Islamic banks, GCC countries

JEL Classifications: G32, G34, G21, G28

\section{Introduction}

Performing the financial intermediation is achieved by means of the Islamic banking and it is referred to as financial institutions that operate with the aim of implementing and materializing the Islamic financial and economic principles in the aspect of banking. According to Hassan (1999), the Islamic banks could be also referred to as financial institutions whose rules, procedures and status clearly show their obligations to the Shariah (Islamic law) principles. This means that the Islamic banking system or activity is guided through the Islamic economics and is in line with the principles of Shariah (Islamic law) (Aburime, 2008). the Islamic banking system is generally regarded nearer to the model of the Swiss-German universal banking compared to the model of the Angelo-Saxon commercial banking (Shahid, 2008). Funds are mobilized in the Islamic banks on the side of liabilities based on Mudarabah (Profit-sharing) or Wakalah (as an agent charging a fixed-fee for managing fund). Regarding the assets, the Islamic banks provide financing on the Mark-up principle or profit and loss sharing (PLS) principle. As a result, the Islamic banks have played the role of investment managers for depositors, apart from demand depositors because they share neither in the reward nor in the risk. Thus, demand deposits are regarded as interest-free loan from the customers to the banks but are to be fully paid by the banks. The integral part of the Islamic banking operations are the asset trading, commodity and equity holding. In this view, the Islamic bank is like the universal bank that operates in several countries in Europe (Shahid, 2008).

Today, the Islamic banking is the fastest growing segment of the credit markets in the Islamic countries. Globally, there are 75 countries which have more than 300 Islamic Financial Institutions in total (Basu, Prasad, \& Rodriguez, 2015). According to The Banker (2015), the total assets held by the Islamic banks represent 28.6 percent from 
USD639 billion in 2008 to USD822 billion in 2009 and increased to USD1.3 trillion in 2010 (increased by 58.2 percent). In this regard, Ernest and Young (2013) mentioned that the total Islamic finance assets of the Islamic banks rose to 17.6 percent between 2009 and 2013, thereby reaching USD78 billion in 2013. Accordingly, the GCC countries account for around USD517 billion, the Asian countries account for USD160 billion and South Asia accounts for USD23 billion, whereas the rest of the world (especially Turkey) makes up the remaining USD78 billion (Al-hersh, 2014). Consequantly, the total Islamic finance assets reached to USD3 trillion in the end of 2016 (Eurasia Review, 2011). Interestingly, the growth of the Islamic banking mainly comes from the GCC countries namely UAE, Qatar, KSA, Kuwait, Bahrain, and Oman, which accounts for USD353.2 billion or 42.9 percent of the global aggregate, whereas Iran alone accounts for 35.6 percent of the market for Shariah-compliant assets (Amba \& Almukharreq, 2013).

The rapid increase of the interest on Islamic banking and their resistance to the global financial crisis implies significant to examine whether the Islamic banks financial leverage affects their performance. The GCC region has one of the world's largest Islamic banking markets. These Islamic banks constitute an important source of financial intermediation, controlling on average 24 percent of the region's banking system assets (Al-Hassan, Khamis, \& Oulidi, 2010). However, the majority of the prior studies in GCC countries have not examined the effect of the financial leverage on the Islamic bank's performance (Poghosyan and Hesse, 2009; Mirzaei and Moore, 2016; Ashraf, Ramady, \& Albinali, 2016; Saif-Alyousfi, 2019; Saif-alyousfi, Md-Rus, \& Mohd, 2018; Saif-Alyousfi, Saha, \& Md-Rus, 2017a, 2017b, 2018b, 2018c, 2018a). Hence, this study aims at filling this gap by examining the effect of the financial leverage on the performance of the Islamic banks' performance during the period from 2005 to 2017. As shown in the World Bank database, the Islamic banks in the GCC economies have an average of 1.33 in their financial leverage. The highest percentage of the financial leverage is recorded in Bahrain and UAE with 1.90 and 1.70 respectively. On the other hand, the Islamic banks of KSA and Oman recorded the lowest average of financial leverage. Compared to other countries, the average level of the financial leverage of the Islamic banks in GCC region is higher than that of Bangladesh (0.40), Malaysia (0.45) Pakistan (0.79), and Turkey (1.66), whereas it is lower than that of Indonesia (1.95).

This study contributes to the extant literature on Islamic banks. It is also among the first studies that examines the effect of the financial leverage on the Islamic banks in the GCC countries which share some common economic, cultural, and political similarities, which outweigh any differences they might have. In addition, this study is among the first studies that use different definitions of the banks' performance to validate the robustness of the results. In other words, this study used the ROA to measure the performance of the banks as well as utilised the ROE and Tobin's Q.

The results show that financial leverage has a positive and significant relationship with the performance of the Islamic banks in the GCC economies. This indicates that the higher is the equity ratio, the higher is the performance of the Islamic banks (ROE, ROE, and Tobin's Q) in the region. However, these results do not provide evidence to support the Agency Cost Theory that implies a decrease in the performance when the equity ratio is increased. In contrased, these findings support the Signaling Theory that argues that the banks are expected to a have better performance in credibly transmitting this information through the higher capital.

The remainder of this paper is organized as follows: section 2 reviews the related studies and section 3 describes the method used in this study. Section 4 shows the analysis, whereas section 5 reports the conclusions.

\section{Literature Review}

The ratio of debt to equity is very much common and has a got significant attention in the existing body of literature. It is measured through the total value of debt over time divided by the value of the total equity in the balance sheet of the business. The ratio of debt to equity provides the fact on how much in terms of percentage the debt and equity are representing each other. Regarding the key assumption under the title of the agency cost in the Agency Theory, higher value of the financial leverage causes a decline in the value of the agency cost. In this regard, Berger and Di Patti (2002) found that the increase in the value of leverage ratio cause a low level of agency cost and more performance to the firm while keeping all other factors constant.

In other studies, Both Khan (2012) and Pandey (2009) found a positive and significant association between the financial leverage and the financial performance of their selected firms. They also argue that the financial leverage is like a double edge sword which can either contribute to the increase in the performance of the selected firms with the lower cost of agency or the at the same time lower the financial performance due to the high risk involved in the business. 
In addition, studies by Fabian et al,. (2014), Kuria and Omboi (2015) and Njeri and Kagiri (2013) indicate a significant and positive level of correlation between the measurement of the financial performance; ROE and ROA and the value of the financial leverage over time. As another study by Jensen (1986) explained that the profit-making firms might have a level of quality by leveraging up, their positive relationship between the financial performance and the leverage as well. Some other studies have shown that a significant negative association exisits between the financial leverage and the key performance indicators as reported by Majumdar and Chhibber (1999), Gleason, Lynette and Ike (2000), Simerly and Li (2000), Hammes (2003), Mesquita and Lara (2003), Zeitun and Tian (2007) and Awunyo-Vitor and Badu (2012).

The empirical findings based on the association between the financial leverage and the performance in terms of the profitability have a subject matter in various studies (Jensen \& Meckling, 1976). However, the association of these factors has indicated mixed findings in terms of the value of of firm and the financial leverage as reported in the studies of Taub (1975), Roden and Lewellen (1995), Champion (1999), Ghosh and Jain (2000), Hadlock and James (2002), and Berger and Bonaccorsi (2006). These studies have proved a significant association between leverage and the financial performance since the financial leverage increase the cost of debt like interest. Hutchinson (1995) explained that level of financial leverage which is committed by the business firm based on the flexibility in which a firm can adjust its value of debt usage and earning power (Hadlock \& James, 2002).

Studies by Kyereboah and Coleman (2007) have investigated the idea that a high debt value has a positive link with the performance of the micro finance firms in the region of the Saharan Africa. On the other hand, various studies focusing mainly on a specific state or country has provided a negative association between the value of the financial leverage and the firm's value, such as Abor (2005) in Ghana, Abor (2007) in South Africa and Ghana, Amidu (2007) in Ghana, Onaolapo and Kajola (2010) in Nigeria, (Odongo, Thabang and Maina (2014) in Kenya. Some studies have provided the evidence that a significant and negative association exists between the return on equity factor and the financial leverage as revealed by Abubakar (2015), Kuria and Omboi (2015), Sagara (2015) and Kipesha and Moshi (2014). For instance, Al-Taani's (2013) study has analyzed the impact of key factors of the capital structure on the performance of 12 banks working in Jordan that are listed in Amani Stock Exchange ASE. The time duration is from 2007 to 2011, wherby the leverage ratio of these banks has a significant determinant for the key profitability factors like the net interest margin. Al-Taani also explained that the financial leverage has an insignificant association with the return on the capital employed and the net profit value. After analyzing the impact of the capital structure elements and the key performance indicator in Tehran Stock market, Farokh (2015) explained a significant and positive link between the debt to equity ratio and ROE, ROA and EPS. Besides he also explained that ROA has a negative association with the financial leverage among the selected firms. In another study, Lim (2015) examined the association between the capital structure and profitability of 11 banking firms working in Philippines during the period from 2006 to 2013 for the debt to equity ratio and return on equity. The findings of Lim's study showed that higher leverage firms are leading to a higher level of financial rewards in the form of profitability.

Moreover, the results of Onyenwe and Glory (2017), confirm the existence of a negative and significant association between the financial leverage and the bank's performance. Another study by Dey, Hossain and Rahman (2018), shows that, the performance which is measured by ROA and Tobin's Q is negatively correlated with the financial leverage. Futher, some studies by Kuria and Omboi (2015) examined the extent to which the factors of capital structure put their influence on the financial performance by examining the secondary data for the investment companies and banking institutions which are listed in NSE. Their findings state the idea that the financial leverage has a negative link with the performance indicators of ROA and ROE. Furthermore, their study illustrated that the financial performance is significantly defined by the financial leverage indicators. In their study, Ronoh and Ntoiti (2015) explain that the capital structure and the financial performance are closely related to each other in the listed banks of Kenya during the period from 2009 to 2013. Hence, their study suggested that the financial leverage is significantly and negatively associated with the return on equity and return on assets. Their findings are quite similar to the study of Abubakar (2015), but the significance level of ROE is at 5 percent level of significance and at 95 percent level of confidence.

Another study by Meero (2015) explained that the leverage has a negative effect on the return on assets. This effect is significant and is in line with the findings of Maksimovic and Titman (1991), Myers (1977) and Coricelli, Driffield, Pal and Roland (2012). The findings of Meero (2015) are also consistent with the Pecking Order Theory and the findings of Rajan and Zingales (1995), Fama and French (2002), Delcoure (2007), Daskalakis and Psillaki (2008), Chakraborty (2010), Kayo and Kimura (2011), Jõeveer (2013), Chakraborty (2013) and Dang (2013). In another study, Meero (2015) considered the returns on the assets mentioning no significant association between the level of the financial leverage as calculated through debt to equity ratio and the return on equity for the Islamic 
banking firms. Conseuently, various studies have been conducted on the relationship between the financial leverage banks' performance focusing mainly on the developed financial market. However, very few studies have been conducted in developing the financial markets. This suggests the need for more studies to be conducted in developing the financial markets such as the GCC countries.

\section{Methodology}

\subsection{Data Environment}

The population of this study involved the Islamic banks in the GCC countries. Thirteen years (i.e., 2005 to 2017) data of 25 listed Islamic banks in GCC countries were used, which resulted in unbalanced data of 294 firm-year observations. The data were retrieved from the Thomson Reuters DataStream.

\subsection{Variables Measurement and Model Specification}

The measurements for the variables are depicted in Table 1 below.

Table 1. Variables measurement

\begin{tabular}{|c|c|c|}
\hline Variables & Connotation & Measurement \\
\hline \multicolumn{3}{|l|}{ Dependent Variables } \\
\hline Return on Assets & ROA & Net income to total assets \\
\hline Return on Equity & ROE & Net income to common equity \\
\hline Tobin's Q & Tobin's Q & $\begin{array}{l}\text { (Market value of equity + book value of liabilities) to Book } \\
\text { value of assets }\end{array}$ \\
\hline \multicolumn{3}{|c|}{ Independent Variables } \\
\hline Financial Leverage & FL & Equity to total liabilities \\
\hline \multicolumn{3}{|l|}{ Control variables } \\
\hline Asset Tangibility & AT & Total fixed assets to total assets \\
\hline Liquidity Risk & LR & Loans to customer and short-term funding \\
\hline Bank Efficiency & $\mathrm{BE}$ & Cost to total income \\
\hline Credit Risk & $\mathrm{CR}$ & Non-performing loan to total labilities \\
\hline Bank Size & SIZE & Logarithm of total assets \\
\hline Bank's Age & AGE & Logarithm of years of operation \\
\hline
\end{tabular}

The data is estimated through the following model:

$$
\begin{gathered}
R O A_{i t}=\beta_{0}+\beta_{1} \mathrm{FL}+\beta_{2} \mathrm{AT}+\beta_{3} \mathrm{LR}+\beta_{4} \mathrm{BE}+\beta_{5} \mathrm{CR}+\beta_{6} \mathrm{SIZE}+\beta_{7} A G E+\varepsilon_{i t} \\
R O E_{i t}=\beta_{0}+\beta_{1} \mathrm{FL}+\beta_{2} \mathrm{AT}+\beta_{3} \mathrm{LR}+\beta_{4} \mathrm{BE}+\beta_{5} \mathrm{CR}+\beta_{6} \mathrm{SIZE}+\beta_{7} A G E+\varepsilon_{i t} \\
\text { Tobin's } Q_{i t}=\beta_{0}+\beta_{1} \mathrm{FL}+\beta_{2} \mathrm{AT}+\beta_{3} \mathrm{LR}+\beta_{4} \mathrm{BE}+\beta_{5} \mathrm{CR}+\beta_{6} \mathrm{SIZE}+\beta_{7} A G E+\varepsilon_{i t}
\end{gathered}
$$

Where,

$\mathrm{ROA}=$ Return on Assets; ROE= Return on Equity; Tobin's Q; FL= financial leverage; AT= Asset Tangibility; LR $=$ Liquidity Risk; $\mathrm{BE}=$ Bank Efficiency; $\mathrm{CR}=$ Credit Risk; SIZE $=$ Bank Size; AGE $=$ Bank Age; $\varepsilon_{\text {it }}=$ idiosyncratic shocks/ error term.

The first equation (1) is testing the relationship between financial leverage and return on assets. The second equation (2) is testing the relationship between financial leverage and return on equity. The third equation (3) is testing the relationship between financial leverage and Tobin's Q.

\section{Analyses and Findings}

\subsection{Summary Statistics}

The summary of the statistics of the data collected for this study is depicted in Table 2 below. ROA indicate a mean of 2.86 percent, which implies that the banks generate 2.86 percent profitability on average through the efficiently 
use of assets in generating the income. In addition, the minimum ROA generated is -27.6 percent, and the maximum is 34.84 percent. Also, the low standard deviation of 5.34 percent, it suggests that there is shorter variation in ROA the among the Islamic banks in the GCC countries.

Table 2. Descriptive statistics of listed Islamic banks in GCC countries

\begin{tabular}{lllllllll}
\hline & Obs & Mean & Std. Dev. & Min. & Max. & Skewness & Kurtosis & Jarque-Bera \\
\hline ROA & 294 & 2.8608 & 5.3488 & -27.600 & 34.840 & -1.1831 & 17.314 & 2578.37 \\
\hline ROE & 294 & 10.226 & 15.294 & -47.620 & 69.920 & -0.8335 & 6.8666 & 217.178 \\
\hline Tobin's Q & 294 & 1.0911 & 0.2259 & 0.2007 & 1.9976 & 0.6858 & 5.6626 & 109.889 \\
\hline FL & 294 & 20.243 & 18.084 & 1.1668 & 91.740 & 1.9878 & 7.0656 & 396.101 \\
\hline AT & 294 & 18.810 & 14.841 & 4.1371 & 97.065 & 2.8651 & 12.691 & 1552.68 \\
\hline LR & 294 & 8.9805 & 13.317 & 0.0345 & 96.110 & 4.1276 & 23.297 & 5881.30 \\
\hline BE & 294 & 63.065 & 29.025 & 0.8189 & 99.910 & -0.9831 & 2.8021 & 47.8331 \\
\hline CR & 294 & 4.8762 & 4.3384 & 0.0332 & 25.821 & 1.2195 & 4.4907 & 100.094 \\
\hline SIZE & 294 & 15.790 & 1.6143 & 12.147 & 21.661 & 0.9765 & 5.4881 & 122.558 \\
\hline AGE & 294 & 2.8623 & 0.9194 & 0 & 4.1109 & -0.8287 & 2.6215 & 35.4012 \\
\hline
\end{tabular}

ROE showed a mean of 10.23 percent, a minimum and maximum of -47.62 percent and 69.92 percent, respectively. These findings imply that the GCC Islamic banks generate 10.23 percent profitability on average through using the equity efficiently in generating the income. The standard deviation showed a low percentage of 15.29 , which indicates a smaller difference in ROE among the GCC Islamic banks. Tobin's Q depicts a mean of 1.09, a minimum of 0.20 and a maximum of 1.99 percent, respectively. This finding indicates that on an average of 1.09 percent, the market value of assets of the Islamic banks is greater than the book value of their assets. Also, the low standard deviation of 0.23 implies very little difference in Tobin's Q among the banks. In addition, the FL showed a mean of 20.43 percent, a minimum of 1.17 percent and a maximum of 91.74 percent. This indicates that on average, 20.43 percent of the assets of the Islamic banks were financed through the debt and other obligations. The low standard deviation of 18.08 percent shows a smaller difference in the financial leverage among the Islamic banks.

AT showed a mean of 18.81 percent, a minimum of 4.14 percent and a maximum of 97.07 percent. This implies that 18.81 percent of the assets of the Islamic banks were averagely invested in the fixed assets. The standard deviation of 14.84 percent showed a low variation in the asset tangibility among the Islamic banks. Also, LR showed a mean of 8.98 percent, a minimum of 0.04 percent and a maximum of 96.11 percent. This finding implies that the Islamic banks are strongly liquid on an average of 8.98 percent. The standard deviation of 13.32 percent showed a low variation in liquidity risk among the Islamic banks. In addition, BE showed a mean of 63.07 percent, a minimum of 0.82 percent and a maximum of 99.9 percent. This suggests that the Islamic banks efficiently and strongly manage their operating expenses over their income on an average of 63.07 percent. The low standard deviation of 29.02 percent indicates little difference in the bank's efficiency among the Islamic banks.

Moreover, CR showed a mean of 4.88 percent, a minimum of 0.03 percent and a maximum of 25.82 percent. This implies that the degree of risk of loss incurred by the Islamic banks from non-performing loans is on an average of 4.88 percent. Consequently, a low standard deviation of 4.34 was achieved, which implies a low variation in the CR among the Islamic banks. Furthermore, the SIZE showed a mean of 15.79 percent, a minimum of 12.15 percent and a maximum of 21.66 percent. This infers that the average size of the Islamic banks is 15.79 percent that is higher than their total assets. The standard deviation of 1.61 percent indicates a low difference in the SIZE among the Islamic banks. Finally, the AGE showed a mean of 2.86 years, a minimum of 0 year and a maximum of 4.11 years. This indicates that the average number of years of operation of the Islamic banks used in this study is 2.86 years. However, the standard deviation of 0.92 year implies a low difference in AGE among the Islamic banks. 


\subsection{Correlation Matrix}

The results of the correlation in Table 3 below shows that the coefficients of the variables are not greater than the threshold of 0.87 or 0.97 based on the suggestion of Field (2009). Therefore, there is no presence of multicollinearity in these variables in each of the models.

In addition, the financial leverage has a negative significant correlation with ROA, but it has a positive significant correlation with Tobin's Q, thereby implying that the lower is the financial leverage the lower is the ROA (Abubakar, 2015; Kuria \& Omboi, 2015a; Meero, 2015), and the higher the financial leverage the higher the market value (Berger \& Bonaccorsi, 2006; Njeri \& Kagiri, 2013; Opoku et al. 2013).

Table 3. Pearson correlation matrix for GCC countries Islamic banks

\begin{tabular}{|c|c|c|c|c|c|c|c|c|c|c|}
\hline & ROA & ROE & Tobin's Q & FL & AT & LR & $\mathrm{BE}$ & CR & Size & Age \\
\hline ROA & 1.000 & & & & & & & & & \\
\hline ROE & 0.659 & 1.000 & & & & & & & & \\
\hline Tobin's Q & 0.050 & 0.119 & 1.000 & & & & & & & \\
\hline FL & -0.044 & -0.151 & 0.048 & 1.000 & & & & & & \\
\hline AT & -0.102 & -0.139 & 0.087 & 0.773 & 1.000 & & & & & \\
\hline LR & -0.161 & -0.244 & -0.137 & 0.178 & 0.066 & 1.000 & & & & \\
\hline $\mathrm{BE}$ & -0.207 & -0.381 & -0.377 & 0.044 & -0.156 & 0.207 & 1.000 & & & \\
\hline $\mathrm{CR}$ & 0.024 & -0.196 & -0.219 & -0.013 & -0.167 & 0.593 & 0.465 & 1.000 & & \\
\hline Size & 0.162 & 0.364 & 0.052 & -0.397 & -0.420 & -0.201 & -0.352 & -0.218 & 1.000 & \\
\hline Age & 0.102 & 0.194 & -0.039 & -0.491 & -0.573 & 0.110 & 0.170 & 0.273 & 0.244 & 1.000 \\
\hline
\end{tabular}

\subsection{Panel Regression Analysis}

The result of the Hausman test confirmed the use of fixed effects method for the datasets of this study, thus, Table 4 showed the results of the fixed effects on each model and give full details on how the focus variables and control variables which are known as predictors affect performance of the Islamic banks.

Table 4 also depicts the fixed regression results to examine the effect of the financial leverage on the performance of the Islamic banks in the GCC countries. The results of the regression show that the overall model fits for the F statistics of 0.0000 in all the models regressed. Model 1 (with ROA as a dependent variable) shows an overall R-square of 0.1046 which indicates that the independent variables and control variables employed in this study explain 10.46 percent variation in ROA of the Islamic banks. Model 2 (with ROE as a dependent variable) show an overall R-square of 0.1414 which indicates that the independent variables and the control variables employed in this study explained 14.14 percent variation in ROE of the Islamic banks. However, Model 3 (with Tobin's as dependent variable) showed an overall $\mathrm{R}$-square of 0.4715 which indicates that the independent variables and the control variables employed in this study explained 47.15 percent variation in Tobin's $Q$ of the Islamic banks.

Table 4. Fixed effect regression results for the models

\begin{tabular}{llll}
\hline & Model 1 & Model 2 & Model 3 \\
& ROA & ROE & Tobin's Q \\
\hline FL & $0.1509^{*}$ & $0.0526^{*}$ & $-0.0324^{* *}$ \\
\hline AT & $(1.68)$ & $(1.79)$ & $(-2.07)$ \\
\hline & $1.1274^{* * *}$ & -2386 & -0.0332 \\
\hline LR & $(3.69)$ & $(-0.92)$ & $(-0.48)$ \\
\hline
\end{tabular}




\begin{tabular}{llll}
\hline & $(0.22)$ & $(-2.02)$ & $(-2.80)$ \\
\hline BE & 0.1350 & $-0.7324^{* * *}$ & $-0.0080^{* * *}$ \\
\hline CR & $(1.23)$ & $(-3.02)$ & $(-11.90)$ \\
\hline & -0.0041 & -0.1210 & $0.0133^{* *}$ \\
\hline SIZE & $(-1.35)$ & $(-1.07)$ & $(2.46)$ \\
\hline & $-13.5769^{* *}$ & -4.5030 & -0.0031 \\
\hline AGE & $(-2.16)$ & $(-1.62)$ & $(-0.04)$ \\
\hline & 0.0290 & $0.3215^{* *}$ & -0.0023 \\
\hline Constant & $(0.09)$ & $(2.65)$ & $(-0.06)$ \\
\hline & $16.6190^{* *}$ & $7.0656^{* *}$ & $0.6341^{* * *}$ \\
\hline Observations & $(2.43)$ & $(2.11)$ & $(5.77)$ \\
\hline R-sq: within & 294 & 294 & 294 \\
\hline between & 0.1424 & 0.1064 & 0.4175 \\
\hline overall & 0.1017 & 0.2867 & 0.5207 \\
\hline F-Statistic & 0.1046 & 0.1414 & 0.4715 \\
\hline P-Value (F-Statistic) & 6.22 & 4.46 & 26.82 \\
\hline & 0.0000 & 0.0001 & 0.0000 \\
\hline
\end{tabular}

The financial leverage (FL) has a positive significant relationship with ROA (at $b=0.1509, p<0.10$ ) and ROE (at $b=$ $0.0526, \mathrm{p}<0.10$ ), and Tobin's $\mathrm{Q}$ (at $\mathrm{b}=-0.0324, \mathrm{p}<0.05$ ). This implies that 100 percent increase in the financial leverage will increase ROA and ROE of the Islamic banks by 15.09 percent, 5.26 percent and 3.24 percent. However, this result is not in line with the previous studies such as Abubakar (2015), Kipesha and Moshi (2014), Kuria and Omboi, (2015), Meer (2015), and Al-Kayed et al. (2014). On the other hand, this result is consistent with Berger and Bonaccorsi (2006), Kuria and Omboi (2015), Lim (2015), Njeri and Kagiri (2013), and Opoku et al. (2013). More specifically, this result is in contrast with the Agency Cost Theory which predicts a decrease in the performance when the equity ratio is increased. This theory argues that a decrease in the equity ratio should increase the performance through the discipline of the managers. In contrast, these findings are in line with the Signaling Theory in which the banks are expected to have a better performance in credibly transmitting this information through the higher capital. In this regard, Al-Kayed et al. (2014) argue that the positive effect of the financial leverage on the Islamic banks' performance may be due to several reasons. First, the increases in the capital can raise the expected earnings by reducing the expected costs of the bankruptcy or liquidation. Second, the higher capital avoids expropriation problems between the shareholders and the creditors. The Islamic banks may optimally choose to increase their capital ratios to assure to the creditors that their interests are closely aligned with those of the shareholders and that the shareholders are unlikely to engage in expropriation activities and that the bank is safe. These increases in the capital ratios by the Islamic banks are made to avoid the creditors' demand for compensation in the form of higher returns on their deposits for the expected expropriation of their claims by the shareholders. Third, a higher equity ratio may also cause higher profitability if the higher capital reduces the risk-related barriers to entry or expansion into some profitable product lines. Consequently, the banks that increase the capital and reduce the risk of failure may be better able to take advantage of opportunities to issue off-balance sheet guarantees, such as commitments and standby letters of credit.

Based on the control variables, the asset tangibility (AT) has a positive significant relationship with ROA (at $b=$ $1.1274, \mathrm{p}<0.01$ ). This result indicates that 10 percent increase in the asset tangibility will increase ROA by 11.27 percent. This finding is consistent with the previous studies (Al-Shubiri, 2009; Jensen \& Meckling, 1976). Regarding the liquidity risk (LR), it has a negative significant relationship with ROE (at $b=-0.0085, p<0.10$ ) and Tobin's Q (at $\mathrm{b}=-0.0057, \mathrm{p}<0.01)$. This means that 100 percent decrease in the liquidity risk will increase ROE by 0.85 percent and Tobin's Q by 0.57 percent, which is in line with the findings of the previous studies (Bourke, 1989; Kosmidou $e t$ al., (2005). Concerning the bank efficiency (BE), it has a negative significant relationship with ROE (at $b=-0.7324$, 
$\mathrm{p}<0.01$ ) and Tobin's $\mathrm{Q}(\mathrm{at} \mathrm{b}=-0.0080, \mathrm{p}<0.01$ ). This result indicates that 100 percent decrease in the bank's efficiency will increase ROE and Tobin's Q of the Islamic bank by 73.24 percent and 0.80 percent, respectively. This result is consistent with the study of Al-Kayed et al., (2014) which found a negative significant relationship between the bank's efficiency and the bank's performance.

On the other hand, the credit risk (CR) has a positive significant relationship with Tobin's $Q$ (at $b=0.0133, p<0.05$ ). This is an indication that 100 percent increase in the credit risk will increase Tobin's Q by 1.33 percent. As a result, this finding is consistent with the previous studies (e.g., Hakim \& Neami, 2001; Nabilah \& Rashidah, 2013). As for the Bank size (SIZE), it has a positive significant relationship with ROA (at $b=-13.5769, \mathrm{p}<0.05$ ). This implies that 5 percent increase in the bank size will increase ROA by 0.68 percent. Regarding the Bank Age (AGE), it has a positive significant relationship with ROE (at $b=0.3215, p<0.05$ ), which indicates that 100 percent increase in the bank age will increase ROE of the Islamic banks in the GCC countries by 32.15 percent.

\section{Conclusion}

This study examines the effect of the financial leverage on the performance of Islamic banks in the GCC countries. ROA, ROE and Tobin's Q are used as proxies for the Islamic banks' performance, wheras the financial leverage is the main independent variable. A total data of 25 public listed Islamic banks for the period from 2005 to 2017 from five GCC countries namely Saudi Arabia, Qatar, Kuwait, United Arab Emirates and Bahrain were analysed in this study.

The results show that the financial leverage has a positive and significant relationship with the performance of the Islamic banks in the GCC economies. This indicates that the higher is the equity ratio, the higher is the performance of the Islamic banks (ROE, ROE, and Tobin's Q) in the region. However, these results do not provide evidence to support the Agency Cost Theory that implies a decrease in the performance when the equity ratio is increased. In contrast, these findings support the Signaling Theory that argues that the banks are expected to have a better performance in credibly transmitting this information through the higher capital.

The findings of this study imply a need for the Islamic banks to maintain high financial leverage to achieve high efficiency in terms of profitability or maintain low financial leverage to reduce the risk. Also, the Islamic banks with higher leverage can achieve a higher level of financial rewards in the form of profitability, which could occur through tax savings, or they incur more cost of debt such as interest, thus reducing the profitability. Based on this, the level of the financial leverage committed by the Islamic banks will depend on their flexibility in adjusting their debt value and earning power. It is worthmetioning that this study focuses mainly on the Islamic banks in the GCC countries. Therefore, further studies are needed to examine both listed and unlisted Islamic banks in the GCC region to further strengthen the findings of this study.

However, the data of the Islamic banks in Oman are not included in this study due to the date of the establishment of the banks and it still has incomplete data. Therefore, the pattern of optimal capitula structure of the Islamic banks in Oman is not captured in this study. Although, this study used the combination of equity to debt ratio (through financial leverage) as a measure to achieve the optimal level of the capital structure when there a is maximum value for the banks, other measurements can be used to achieve the optimal level of the capital structure which is not considered in this study, namely the weighted average cost of the capital (WACC).

Obviously, this study focused only on the Islamic banks in the GCC countries. There are more than one hundred Islamic banks globally, and only fifty-one of them are in GCC countries, whereas only twenty-five of them are considered in this study. Accordingly, the findings of this study cannot be generalized on all the Islamic banks globally. Since the GCC consists of six countries namely Saudi Arabia, Qatar, UAE, Bahrain, Kuwait and Oman with a different economic development and a business environment, the probability of individual country effect on the impact of the financial leverage on the Islamic banks' performance is not considered in this study. Therefore, the impact of the financial leverage on the Islamic banks' performance analyzed in this study is at the level of the combination of the GCC countries rather than the individual levels of the countries in the GCC.

It is worth noted that the findings are limited to the financial listed banks. Therefore, there should be caution in generalizing the findings of this study to non-financial listed banks. In other words, the financial firms have different accounting regulations from the non-financial firms and their financial characteristics are mostly different from the non-financial firms. 


\section{References}

Abor, J. (2005). The effect of capital structure on profitability: an empirical analysis of listed firms in Ghana. The Journal of Risk Finance, 6(5), 438-445. https://doi.org/10.1108/15265940510633505

Abor, J. (2007). Debt policy and performance of SMEs: evidence from Ghanaian and South Africa firms. Journal of Risk and Finance, 8, 364-379. https://doi.org/10.1108/15265940710777315

Abubakar, \& Ahmadu. (2015). Relationship Between Financial Leverage and Financial Performance of Deposit Money Banks in Nigeria. International Journal of Economics, Commerce and Management United Kingdom, 3(10), 759-778.

Aburime, T. U. (2011). Determinants of Bank Profitability: Company-Level Evidence from Nigeria. SSRN Electronic Journal, 1-31.

Al-Hassan, A., Khamis, M., \& Oulidi, N. (2010). The GCC banking sector: Topography and analysis. IMF Working Papers, 10(87), 1-45. https://doi.org/10.5089/9781451982619.001

Al-hersh, N. (2014). The advancement of Islamic banking and Finance in Global Markets. International Journal of Interdisciplinary and Multidisciplinary Studies, 1(8), 11-18.

Al-Kayed, L. T., Zain, S. R. S. M., \& Duasa, J. (2014). The relationship between capital structure and performance of Islamic banks. Journal of Islamic Accounting and Business Research, 5(2), 158-181. https://doi.org/10.1108/JIABR-04-2012-0024

Al-Shubiri, F. N. (2011). Capital Structure and Market Power: Evidence from Jordanian Banks. Managing Global Transitions, 9(3), 289-310.

Al-Taani, K. (2013). The Relationship between Capital Structure and Firm Performance: Evidence from Jordan. Journal of Finance and Accounting, 1(3), 41-45. https://doi.org/10.11648/j.jfa.20130103.11

Amba, M. S., \& Almukharreq, F. (2013). Impact of the Financial Crisis on Profitability of the Islamic Banks vs Conventional Banks-Evidence from GCC. International Journal of Financial Research, 4(83), 1923-4023.

Ashraf, D., Ramady, M., \& Albinali, K. (2016, September). Financial fragility of banks, ownership structure and income diversification: Empirical evidence from the GCC region. Research in International Business and Finance, 38, 56-68. https://doi.org/10.1016/j.ribaf.2016.03.010

Awunyo-Vitor, D., \& Badu, J. (2012). Capital Structure and Performance of Listed Banks in Ghana. Global Journal of Human Social Science, 12(5).

Basu, R., Prasad, A., \& Rodriguez, S. (2015). Monetary Operations and Islamic Banking in the GCC: Challenges and Options. https://doi.org/10.5089/9781513588513.001

Berger, A. N., \& Bonaccorsi, di P. E. (2006). Capital Structure and Firm Performance: A New Approach to Testing Pecking Order Theory and An Application to Banking Industry. Journal of Banking and Finance, 30(4), 1065-1102. https://doi.org/10.1016/j.jbankfin.2005.05.015

Bourke, P. (1989). Concentration and other determinants of bank profitability in Europe, North America and Australia. Journal of Banking and Finance, 13, 65-79. https://doi.org/10.1016/0378-4266(89)90020-4

Chakraborty, I. (2010). Capital structure in an emerging stock market: The case of India. Research in International Business and Finance, 24(3), 295-314. https://doi.org/10.1016/j.ribaf.2010.02.001

Champion, D. (1999). Finance: the joy of leverage. Harvard Business Review, 77(4), 19-22.

Coricelli, F., Driffield, N., Pal, S., \& Roland, I. (2012). When does leverage hurt productivity growth? A firm-level Analysisq. Journal of International Money and Finance, 31, 1674-1694.

Dang, V. A. (2013). Testing capital structure theories using error correction models: Evidence from the UK, France and Germany. Applied Economics, 45(2), 171-190. https://doi.org/10.1080/00036846.2011.597724

Daskalakis, N., \& Psillaki, M. (2008). Do country or firm factors explain capital structure? Evidence from SMEs in France and Greece. Applied Financial Economics, 18(2), 87-97. https://doi.org/10.1080/09603100601018864

Delcoure, N. (2007). The determinants of capital structure in transitional economies. International Review of Economics \& Finance, 16(3), 400-415. https://doi.org/10.1016/j.iref.2005.03.005

Fabian, E., \& Moshi, J. (2014). Capital Structure and Firm Performance: Evidences from Commercial Banks in Tanzania. Research Journal of Finance and Accounting, 5(14), 168-178. 
Fama, E. F., \& French, K. R. (2002). Testing trade-off and pecking order predictions about dividends and debt. Review of Financial Studies, 15(1), 1-33. https://doi.org/10.1093/rfs/15.1.1

Ghosh, A., \& Jain, P. C. (2000). Financial leverage changes associated with corporate mergers. Journal of Corporate Finance, 6(4), 377-402. https://doi.org/10.1016/S0929-1199(00)00007-9

Gleason, K. C., Lynette, K. M., \& Ike, M. (2000). The Interrelationship between culture, capital structure, and performance: Evidence from European retailers. Journal of Business Research, 50(2), 185-191.

Grossman, S. J., \& Hart, O. D. (1983). Corporate financial structure and managerial incentives. Working Paper No. R0398. National Bureau of Economic Research.

Hadlock, C. J., \& James, C. M. (2002). Do Banks Provide Financial Slack?. The Journal of Finance, 57(3), 1383-1419. https://doi.org/10.1111/1540-6261.00464

Hakim, S., \& Neami, S. (2001). Performance and Credit Risk in Banking: A Comparative Study of Egypt and Lebanon. ERF Working Paper Series.

Hammes, K. (2003). Firm performance, debt, bank loans and trade credit: An empirical study. Working paper, Department of Economics, Gothenburg University, Gothenburg.

Harris, M., \& Raviv, A. (1990). Capital Structure and the Informational Role of Debt. The Journal of Finance, 45(2), 321-349. https://doi.org/10.1111/j.1540-6261.1990.tb03693.x

Hassan, M. Kabir. (1999) Islamic Banking in Theory and Practice: The Experience of Bangladesh. Managerial Finance, 25(5), 60-113. https://doi.org/10.1108/03074359910765966

Hutchinson, R. W. (1995). The capital structure and investment decisions of small owner-managed firms: Some exploratory issues. Small Business Economics, 7, 231-239. https://doi.org/10.1007/BF01135368

Jensen, M. C. (1986). Agency costs of free cash flow, corporate finance, and takeovers. American Economic Review, 76, 323-329.

Jensen, M., \& Meckling, W. (1976). Theory of the firm: Managerial behaviour, agency costs and ownership structure. Journal of Financial Economics, 3, 305-360. https://doi.org/10.1016/0304-405X(76)90026-X

Jõeveer, K. (2013). What do we know about the capital structure of small firms?. Small Business Economics, 41(2), 479-501. https://doi.org/10.1007/s11187-012-9440-1

Kayo, E. K., \& Kimura, H. (2011). Hierarchical determinants of capital structure. Journal of Banking \& Finance, 35(2), 358-371. https://doi.org/10.1016/j.jbankfin.2010.08.015

Khan, A. G. (2012). The Relationship of capital structure decision with firm performance: A study of the engineering sector of Pakistan. International Journal of Accounting and Financial Reporting, 2, 305-360.

Kipesha, E., \& Moshi, J. (2014). Capital Structure and Firm Performance: Evidences from Commercial Banks in Tanzania. Research Journal of Finance and Accounting, 5(14), 168-178.

Kosmidou, K., Tanna, S., \& Pasiouras, F. (2005). Determinants of profitability of UK domestic banks: Panel evidence from the period 1995-2002. In Proceedings ofthe 37th Annual Conference ofthe Money Macro and Finance (MMF) Research Group.

Kuria, J., \& Omboi, B. (2015). Relationship Between The Capital Structure and The Financial Performance of Investment And Banking Firms Listed at The Nairobi Securities Exchange In Kenya. Prime Journal of Business Administration and Management, 5(11), 1983-1991.

Lim, E. (2015). Capital Structure and Profitability of Selected Universal Banks in the Philippines. 9th Global Business Conference, 24-28.

Majumdar, S. K., \& Chhibber, P. (1999). Capital Structure and Performance: Evidence from aTransition Economy on an aspect of Corporate Governance. Public Choice, 98(3), 287-305.

Maksimovic, V., \& Titman, S. (1991). Financial policy and reputation for product quality. Review of Financial Studies, 4(1), 175-200. https://doi.org/10.1093/rfs/4.1.175

Meero, A. A. (2015). The Relationship between Capital Structure and Performance in Gulf Countries Banks: A Comparative Study between Islamic Banks and Conventional Banks. International Journal of Economics and Finance, 7(12), 140-154. https://doi.org/10.5539/ijef.v7n12p140

Mesquita, J. M. C., \& Lara, J. E. (2003, July 11-13). Capital structure and profitability: the Brazilian case working 
paper. Academy of Business and Administration Sciences Conference, Vancouver.

Mirzaei, A., \& Moore, T. (2016). Banking performance and industry growth in an oil-rich economy: Evidence from Qatar. The Quarterly Review of Economics and Finance, 60(30), 58-69.

Modigliani, F., \& Miller, M. H. (1958). The Cost Of Capital, Corporation Finance and The Theory of Investmient. The American Economic Review, 48(3), 261-297.

Myers, S. C. (1977). Determinants of corporate borrowing. Journal of Financial Economics, 5(2), 147-175.

Njeri, M., \& Kagiri, A. (2013). Effect of Capital Structure on Financial Performance of Banking Institutions Listed in Nairobi Securities Exchange. International Journal of Science and Research, 14(7), 2319-7064.

Odongo, K., Thabang, M., \& Maina, L. (2014). Capital structure, profitability and firm value: panel evidence of listed firms in Kenya. https://doi.org/10.2139/ssrn.2465422

Onaolapo, A. A., \& Kajola, S. O. (2010). Capital Structure and Firm Performance: Evidence from Nigeria. Journal of Economics, Finance and Administrative Sciences, 25, 70-82.

Ongore, V. O., \& Kusa, G. B. (2013). Determinants of financial performance of commercial banks in Kenya. International Journal of Economics and Financial Issues, 3(1), 237-252.

Onyenwe, N. I., \& Glory, I. (2017). Effect Of Financial Leverage on Firm's Performance: A Study of Nigerian Banks (2006-2015). International Journal Of Recent Scientific Research, 8(1960), 18554-18564.

Pandey, I. M. (2009). Financial Management: Capital Structure Planning and Policy.

Poghosyan, T., \& Hesse, H. (2009). Oil prices and bank profitability: Evidence from major oil-exporting countries in the Middle East and North Africa. IMF Working Papers, 09(220), 1-23.

Rajan, R. G., \& Zingales, L. (1995). What do we know about capital structure? Some evidence from international data. Journal of Finance, 50, 1421-1460. https://doi.org/10.1111/j.1540-6261.1995.tb05184.X

Roden, D. M., \& Lewellen, W. G. (1995). Corporate capital structure decisions: evidence from leveraged buyouts. Financial Management, 24, 76-87. https://doi.org/10.2307/3665536

Ronoh, C., \& Ntoiti, J. (2015). Effect Of Capital Structure On Financial Performance of Listed Commercial Banks In Kenya. A Case Study of Kenya Commercial Bank Limited. The Strategic Journal of Business \& Change, 2(72).

Rozzani, N., \& Rahman, R. (2013). Camels and Performance Evaluation of Banks in Malaysia: Conventional Versus Islamic. Journal of Islamic Finance and Business, 2(1), 36-45.

Sagara, S. (2015). The Analysis of Capital Structure on Financial Performance Using Capital, Assets, Earnings, and Liquidity Ratios in Islamic Banks Listed on the Indonesia Stock Exchange (Idx) in 2014. International Journal of Business, Economics and Law, 8(1), 53-60.

Saif-alyousfi, A. Y. H. (2019). Determinants of bank shareholder value: Evidence from GCC countries. International Journal of Managerial Finance, 15(5), 1-27. https://doi.org/10.1108/IJMF-05-2019-0170

Saif-alyousfi, A. Y. H., Md-Rus, R., \& Mohd, K. N. T. (2018). Oil price and banking sectors in Gulf Cooperation Council Economies before and after the global financial turmoil: Descriptive analysis. International Journal of Energy Economics and Policy, 8(6), 89-101.

Saif-Alyousfi, A. Y. H., Saha, A., \& Md-Rus, R. (2017a). Profitability of Saudi Commercial Banks : A comparative evaluation between domestic and foreign banks using CAMEL parameters. International Journal of Economics and Financial Issues, 7(2), 477-484.

Saif-Alyousfi, A. Y. H., Saha, A., \& Md-Rus, R. (2017b). Shareholders' value of Saudi commercial banks: A comparative Evaluation between Islamic and conventional banks using CAMEL parameters. International Journal of Economics and Financial Issues, 7(1), 97-105.

Saif-Alyousfi, A. Y. H., Saha, A., \& Md-Rus, R. (2018a). Impact of oil and gas price shocks on the non-performing loans of banks in an oil and gas-rich economy: Evidence from Qatar. International Journal of Bank Marketing, 36(3), 529-556. https://doi.org/10.1108/IJBM-05-2017-0087

Saif-Alyousfi, A. Y. H., Saha, A., \& Md-Rus, R. (2018b). Impact of oil and gas prices shocks on banks' deposits in an oil and gas-rich economy: Evidence from Qatar. International Journal of Emerging Markets, 13(5), 875-901.

Saif-Alyousfi, A. Y. H., Saha, A., \& Md-Rus, R. (2018c). The impact of bank competition and concentration on bank risk-taking behavior and stability: Evidence from GCC countries. The North American Journal of Economics 
and Finance, 3(2), 1-42. https://doi.org/10.1016/j.najef.2018.10.015

Shahid, H., Ur Rehman, R., Niazi, G. S. K., \& Raoof, A. (2010). Efficiencies comparison of Islamic and conventional banks of Pakistan. International Research Journal of Finance and Economics, 49, 24-42.

Sheikh, N. A., \& Wang, Z. J. (2011). Determinants of capital structure: An empirical study of firms in manufacturing industry of Pakistan. Managerial Finance, 37(2), 117-133. https://doi.org/10.1108/03074351111103668

Simerly, R., \& Li, M. (2000). Environmental dynamism, capital structure and performance: a theoretical integration and an empirical test. Strategic Management Journal, 21, 31-49.

Stulz, R. M. (1990). Managerial discretion and optimal financing policies. Journal of Financial Economics, 26 , 3-27.

Taub, A. J. (1975). Determinants of the Firm's Capital Structure. Review of Economics and Statistics, 57, 410-416.

The Banker (Top Islamic Financial institutional). (2015). The Banker (Top Islamic Financial institutional).

Zeitun, R., \& Tian, G. G. (2007). Capital structure and corporate performance: Evidence from Jordan. The Australasian Accounting Business and Finance Journal, 1(4), 40-61. https://doi.org/10.14453/aabfj.v1i4.3 